University of Nebraska - Lincoln

DigitalCommons@University of Nebraska - Lincoln

USDA Wildlife Services - Staff Publications

U.S. Department of Agriculture: Animal and Plant Health Inspection Service

2018

FIELD TRIALS OF ONTARIO RABIES VACCINE BAIT IN THE NORTHEASTERN USA, 2012-14

Amy Gilbert

APHIS, WS, NWRC, Amy.T.Gilbert@aphis.usda.gov

Shylo R. Johnson

APHIS, WS, NWRC

Kathleen M. Nelson

USDA, APHIS, WS

Richard B. Chipman

USDA, APHIS, WS

Kurt C. VerCauteren

APHIS, WS, NWRC, kurt.c.vercauteren@usda.gov

See next page for additional authors

Follow this and additional works at: https://digitalcommons.unl.edu/icwdm_usdanwrc

Part of the Life Sciences Commons

Gilbert, Amy; Johnson, Shylo R.; Nelson, Kathleen M.; Chipman, Richard B.; VerCauteren, Kurt C.; Algeo, Timothy P.; Rupprecht, Charles E.; and Slate, Dennis, "FIELD TRIALS OF ONTARIO RABIES VACCINE BAIT IN THE NORTHEASTERN USA, 2012-14" (2018). USDA Wildlife Services - Staff Publications. 2186.

https://digitalcommons.unl.edu/icwdm_usdanwrc/2186

This Article is brought to you for free and open access by the U.S. Department of Agriculture: Animal and Plant Health Inspection Service at DigitalCommons@University of Nebraska - Lincoln. It has been accepted for inclusion in USDA Wildlife Services - Staff Publications by an authorized administrator of DigitalCommons@University of Nebraska - Lincoln. 


\section{Authors}

Amy Gilbert, Shylo R. Johnson, Kathleen M. Nelson, Richard B. Chipman, Kurt C. VerCauteren, Timothy P. Algeo, Charles E. Rupprecht, and Dennis Slate 


\title{
FIELD TRIALS OF ONTARIO RABIES VACCINE BAIT IN THE NORTHEASTERN USA, 2012-14
}

\author{
Amy T. Gilbert, ${ }^{1,4}$ Shylo R. Johnson, ${ }^{1}$ Kathleen M. Nelson, ${ }^{2}$ Richard B. Chipman, ${ }^{2}$ Kurt C. \\ VerCauteren, ${ }^{1}$ Timothy P. Algeo, ${ }^{2}$ Charles E. Rupprecht, ${ }^{3}$ and Dennis Slate ${ }^{2}$ \\ ${ }^{1}$ US Department of Agriculture, Animal and Plant Health Inspection Service, Wildlife Services, National Wildlife Research \\ Center, 4101 LaPorte Ave., Fort Collins, Colorado 80521, USA \\ 2 US Department of Agriculture, Animal and Plant Health Inspection Service, Wildlife Services, National Rabies \\ Management Program, 59 Chenell Dr., Concord, New Hampshire 03301, USA \\ ${ }^{3}$ LYSSA LLC, 647 Michelle Ct., Lawrenceville, Georgia 30044, USA \\ ${ }^{4}$ Corresponding author (email: Amy.T.Gilbert@aphis.usda.gov)
}

ABSTRACT: In the US, rabies virus (RV) has been enzootic in raccoons (Procyon lotor) since the late 1940s. Oral rabies vaccination (ORV) was implemented in the 1990s to halt the spread of raccoon RV and continues to be used as a wildlife management tool. Our objective was to evaluate a recombinant human adenovirus-rabies virus glycoprotein vaccine in northern New York, Vermont, and New Hampshire over a 3-yr period, using changes in RV neutralizing antibody (RVNA) seroprevalence in raccoon populations as an immunologic index of ORV impact. Vaccine baits were distributed at 75 baits/ $\mathrm{km}^{2}$ and $750-\mathrm{m}$ flight-line spacing in the study area. Animal sampling occurred during 10-d intervals pre- and post-ORV during 2012-14 within eight study cells: four northern cells had a history of ORV with a different vaccine for 3 or more years prior and four southern cells were ORV naive. Baseline raccoon RVNA seroprevalence was $27.3 \%$ ( $n=1,079,95 \%$ confidence interval [CI]: 24.8-30.1) before ORV in 2012. Raccoon RVNA seroprevalence averaged $68.5 \%$ ( $n=1,551,95 \%$ CI: $66.2-70.8)$ post-ORV during the 3-yr study. The RVNA seroprevalence levels in this study were considered to be adequate for stopping raccoon RV transmission and supported and expanded the results from a West Virginia field trial, as well as earlier evaluations along the Canada-US border.

Key words: Field trial, ONRAB, oral rabies vaccination, rabies, raccoon.

\section{INTRODUCTION}

Rabies virus (RV) has been enzootic in raccoon (Procyon lotor) populations in the US at least since the late 1940 s, with an original focus in the state of Florida (McLean 1971; Bigler et al. 1973). The raccoon RV focus expanded into neighboring states of the southeastern US during the 1960s-70s, but translocation of rabid raccoons in the late 1970s seeded an epizootic that rapidly spread across the US Eastern Seaboard (Nettles et al. 1979; Rupprecht and Smith 1994). With an interest in developing and evaluating intervention tools to combat further spread of RV in raccoon populations, the first field trials for oral rabies vaccination (ORV) in the US occurred in Virginia during 1990 (Hanlon et al. 1998), Pennsylvania during 1991 (Hanlon and Rupprecht 1998), New Jersey during 1992-93 (Roscoe et al. 1998), followed by Massachusetts (Robbins et al. 1998) and New York (Hanlon and Rupprecht 1998) during
1994, and Florida during 1995 (Olson et al. 2000). Under the US Department of Agriculture, Animal and Plant Health Inspection Service, Wildlife Services, National Rabies Management Program (NRMP), coordinated ORV was initiated in 1995. Through 2003, the geographic scale and intensity of ORV targeting wild mesocarnivores expanded significantly (Slate et al. 2005). The broad-scale landscape application of ORV, with supporting contingency actions, effectively halted the westward spread of raccoon RV. However, RV neutralizing antibody (RVNA) seroprevalence averaging $30 \%$ in raccoon populations is likely inadequate to eliminate RV (Slate et al. 2009; Rees et al. 2013).

The only ORV product licensed for use with wildlife in the US is a live recombinant vaccinia virus expressing the rabies virus glycoprotein, contained in a sachet with a fishmeal attractant matrix (RABORAL V$\mathrm{RG}^{\circledR}$, hereafter V-RG; Boehringer Ingelheim Animal Health, Athens, Georgia, USA; Maki 
et al. 2017). To evaluate additional tools for ORV with the goal of eliminating raccoon RV in the US, and as part of cooperative efforts under the North American Rabies Management Plan, the NRMP turned its focus to a Canadian ORV product that had been successful in controlling circulation of an Arctic fox (Vulpes lagopus) RV variant in striped skunk (Mephitis mephitis) populations in Ontario (Rosatte et al. 2011). This product is a live recombinant human adenovirus expressing the rabies virus glycoprotein (AdRG1.3), enclosed in a blister pack with a sweet attractant matrix that contains $100 \mathrm{mg}$ of tetracycline hydrochloride (TTCC) biomarker (Ontario Rabies Vaccine Bait, hereafter ONRAB; Artemis Technologies, Inc., Guelph, Ontario, Canada; Graham and Prevec 1992; Rosatte et al. 2009). Two cross-border cooperative studies between Canada and the US compared the change in target population RVNA seroprevalence before and after ORV: 1) using ONRAB in New Brunswick versus VRG in Maine under an application rate of 75 baits $/ \mathrm{km}^{2}$ (Fehlner-Gardiner et al. 2012), and 2) using ONRAB in Quebec versus V-RG in Vermont under an application rate of 150 baits $/ \mathrm{km}^{2}$ (Mainguy et al. 2013). In both studies, greater RVNA seroprevalence was observed among raccoons from ONRAB ORV areas in Canada compared with raccoons from V-RG ORV areas in the US (FehlnerGardiner et al. 2012; Mainguy et al. 2013). The cross-border comparison studies led to interest in experimental evaluation of ONRAB in the US. The first field trial of ONRAB in the US occurred during 2011 in West Virginia, in an ORV-naive area (Slate et al. 2014). This field trial indicated a significant increase in RVNA from background levels in raccoon populations, with post-ORV levels also higher than those typically observed from nearby areas treated with V-RG at the same bait application rates (Slate et al. 2014).

The experimental evaluation of ONRAB was then expanded to other regions of the US, including areas with a history of V-RG baiting. One trial initiated during 2012 occurred in northern New York, Vermont, and New Hampshire. This area has been an important focus for rabies control, as it shares a border with Quebec, Canada, and has been identified as a high-risk area for reintroduction of raccoon RV into Canada. We describe the results of a 3-yr field trial of ONRAB in northern New York, Vermont, and New Hampshire, which included study areas naive to ORV and areas previously baited with VRG. Our objectives were to evaluate the impact of ORV using ONRAB, measured by increases in RVNA seroprevalence above baseline values in free-ranging raccoon populations, and to identify how the induction of RVNA (as an index to immunity) was affected by raccoon age and sex, while controlling for prior treatment history of areas and ORV application.

\section{MATERIALS AND METHODS}

\section{Study area and design}

The study area encompassed three states and nine counties in the northeastern US: New York (Clinton and Essex counties), Vermont (Addison, Caledonia, Chittenden, Essex, Franklin, and Lamoille counties), and New Hampshire (Grafton County). Eight $132-\mathrm{km}^{2}$ study cells were separated by at least $1.8 \mathrm{~km}$ and buffered by at least 4.7 $\mathrm{km}$ from unbaited areas or where bordered by Lake Champlain (Fig. 1). Four northern study cells had been baited previously with V-RG at least from 2007 to 2011. The overall macrohabitat composition of these study cells was $59 \%$ forested, $20 \%$ agriculture, $10 \%$ developed, and $11 \%$ wetland or water. Four study cells were established farther south, in areas that were ORV naïve from 2009 to 2011 (two cells) or completely ORV naïve (two cells). Their macrohabitat composition was $60 \%$ forested, $26 \%$ agriculture, $6 \%$ developed, and $8 \%$ wetland/water. The macrohabitat compositions were calculated by grouping the 2011 National Land Cover Database into categories on the basis of land class values: forested (values 41, 42, 43, 52), agriculture (values 71, 81, 82), developed (values 21, 22, 23, 24), wetland or water (values 11,90, 95), and other (value 31; Homer et al. 2015).

Given the geographic and political importance, a 16-km-wide portion of the ORV zone along the Canadian border was baited with ONRAB at 150 baits $/ \mathrm{km}^{2}$ (Fig. 1), but this area was not evaluated in this study. In the remainder of the ORV zone, ONRAB baits were distributed at 75 baits $/ \mathrm{km}^{2}$ either aerially, along parallel flight lines spaced at $750-\mathrm{m}$ intervals, or by hand in suburban and 


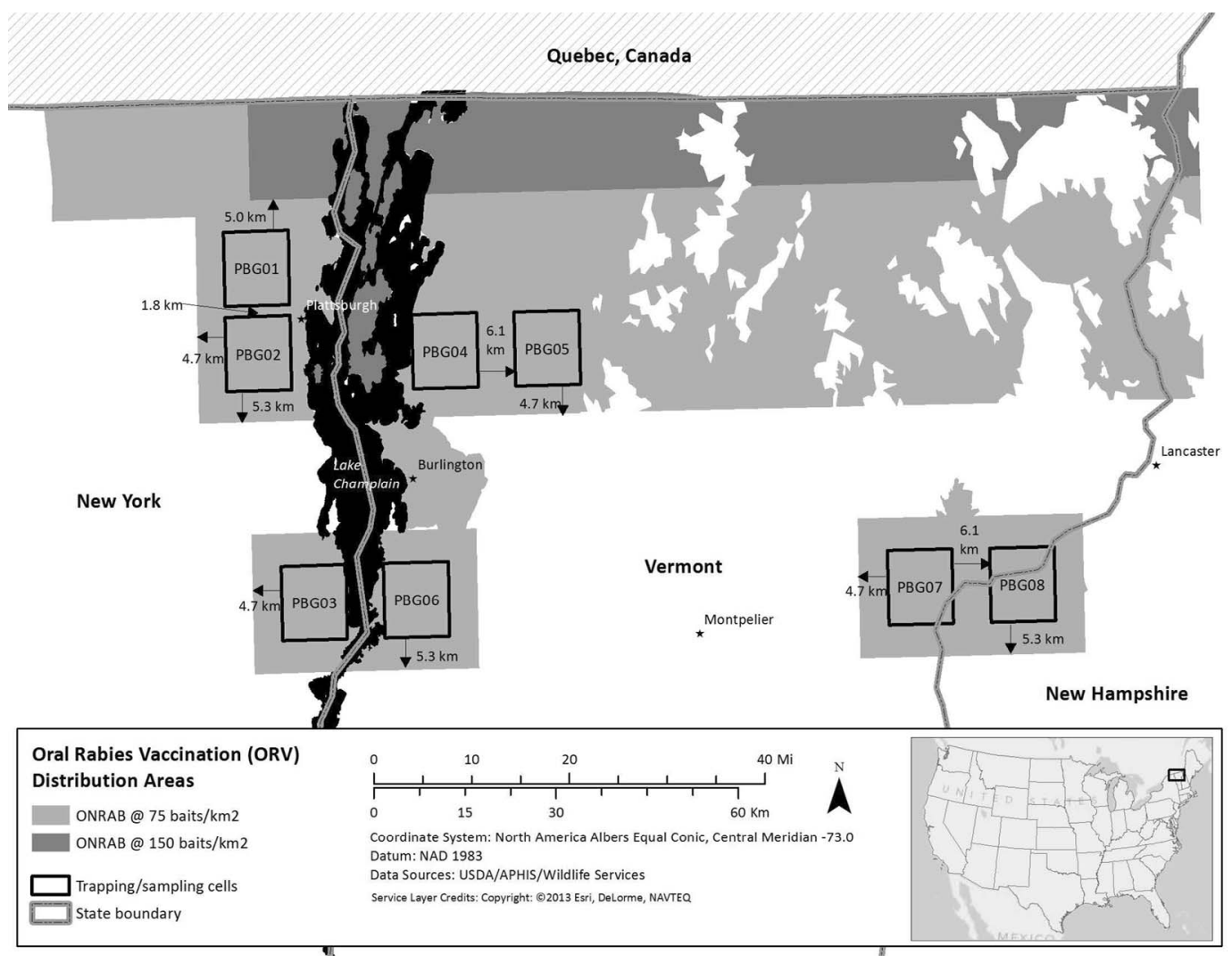

Figure 1. Study area where oral rabies vaccination (ORV) using Ontario Rabies Vaccine Baits $(\mathrm{ONRAB})$ at 75 baits $/ \mathrm{km}^{2}$ was evaluated in the northeastern USA during 2012-14. Northern cells (PBG01, 02, 04, 05) had been baited with vaccinia-rabies glycoprotein before 2012. Southern cells (PBG03, 06, 07, 08) were naïve to ORV before 2012. White areas within the gray ORV zones are $>500 \mathrm{~m}$ in elevation and were not baited because of negligible raccoon presence in those habitats on the basis of previous studies.

urban areas where aerial distribution was operationally impractical or could result in human safety concerns (Table 1). Baits had a warning label with a toll-free number to facilitate communication of potential vaccine exposures to the New York State Department of Health (NYSDOH) or Wildlife Services (in Vermont and New Hampshire).

\section{Animal sampling}

Trapping occurred pre- and post-ORV during 2012-14. Random points, generated using either Hawth's tools (Beyer 2004) in 2012 or Geospatial Modeling Environment (v 0.7.3.0; Beyer 2012) in 2013 and 2014, were used to guide placement of 150 traps in each cell. The same points were used for pre- and post-ORV trapping efforts within a year, with new points generated each year. Animals were live-trapped using cage traps (Tomahawk Live Trap, LLC, Hazelhurst, Wisconsin, USA). Traps were set for 10 consecutive days and checked daily. All nontarget species were released at the point of capture. Captured target species (e.g., raccoons, striped skunks, red foxes [Vulpes vulpes], gray foxes [Urocyon cinereoargenteus], coyotes [Canis latrans], and fishers [Martes pennanti]) were anesthetized using a 5:1 mixture of ketamine:xylazine (i.e., $10 \mathrm{mg} / \mathrm{kg}$ ketamine and $2 \mathrm{mg} / \mathrm{kg}$ xylazine) to determine sex (male or female), relative age (adult or juvenile), weight $(\mathrm{kg})$, to assess general body condition, to collect a blood sample from a peripheral vein, to extract a first premolar tooth, and to apply a uniquely numbered metal tag (National Band and Tag Company, Newport, Kentucky, USA) in each ear. Recaptured target animals were resampled, unless the recapture event occurred within a 10-d sampling period. For recaptures within a sampling period, target animals were released at the point of capture without resampling. Target animals exhibiting normal behavior before anesthesia and in good general body condition were released at 
TABLe 1. Number of Ontario Rabies Vaccine Baits and area $\left(\mathrm{km}^{2}\right)$ subjected to oral rabies vaccination (ORV), by aerial or ground distribution, at $75 \mathrm{baits} / \mathrm{km}^{2}$ in the northeastern USA during 2012-14. Dates of ORV and associated pre- and post-ORV target animal sampling of study cells are listed for each year.

\begin{tabular}{|c|c|c|c|c|c|c|c|}
\hline \multirow[b]{2}{*}{ Year } & \multicolumn{2}{|c|}{ Aerial } & \multicolumn{2}{|c|}{ Ground } & \multicolumn{3}{|c|}{ Trapping dates } \\
\hline & $n$ Baits & Area $\left(\mathrm{km}^{2}\right)$ & $n$ Baits & Area $\left(\mathrm{km}^{2}\right)$ & ORV dates & Pre-ORV & Post-ORV \\
\hline 2012 & 377,885 & 6,782 & 17,730 & 314 & 13-23 August & 10 July-5 August & 24 September-5 October \\
\hline 2013 & 358,265 & 6,782 & 17,358 & 308 & 20-24 August & 10 July-2 August & 19-31 October \\
\hline 2014 & 384,528 & 7,079 & 17,251 & 303 & 12-19 August & 24 June-1 August & 23 September-3 October \\
\hline Total & $1,120,678$ & 20,643 & 52,339 & 925 & & & \\
\hline Mean & 373,559 & 6,881 & 17,446 & 308 & & & \\
\hline
\end{tabular}

the point of capture after recovery from anesthesia. Animals exhibiting abnormal behavior or with suspect lesions or wounds were euthanized in accordance with the American Veterinary Medical Association's Panel on Euthanasia recommendations (e.g., two-stage chemical euthanasia with pentobarbital, sodium pentobarbital, or potassium chloride products; AVMA 2013). Brain-stem tissues were collected in Vermont and New Hampshire, whereas whole heads were collected in New York. In New York, animals suspected of having rabies were tested by NYSDOH Rabies Laboratory using the direct fluorescent antibody test (Centers for Disease Control and Prevention 2017). In Vermont and New Hampshire, animals suspected of having rabies were tested by the Vermont Department of Health Laboratory using the direct fluorescent antibody test. For all positive cases, RV variant typing was performed by the NYSDOH Rabies Laboratory (Szanto et al. 2011). Serum samples were separated from whole blood by centrifugation on the day of capture and stored in labeled cryovials at $-25 \mathrm{C}$ to $-70 \mathrm{C}$ until analysis.

\section{RVNA determination}

Serum RVNA titers were determined using a modified neutralization test (Trimarchi et al. 1996) at the NYSDOH Rabies Laboratory. The cutoff for determining a RVNA seropositive serum was $0.125 \mathrm{IU} / \mathrm{mL}$, on the basis of comparison with a standard rabies immune globulin control, which is the sensitivity threshold for this test. This cutoff level is slightly higher than RVNA titers that have been associated with survivorship against a RV challenge in an experimental study with raccoons (i.e., 0.05 to $0.11 \mathrm{IU} /$ $\mathrm{mL}$; Blanton et al. 2018). We also considered a higher RVNA cutoff of $0.5 \mathrm{IU} / \mathrm{mL}$ as a recognized level of immunity that has been considered a surrogate of protection against RV challenge in raccoons and other wildlife (Moore et al. 2017; Blanton et al. 2018). Samples with test values less than the cutoff were coded as seronegative. At the $0.125 \mathrm{IU} / \mathrm{mL}$ cutoff, a total of 59 raccoon and four skunk samples, constituting $1 \%$ of all samples, could not be evaluated (e.g., samples reported with RVNA less than $0.25 \mathrm{IU} / \mathrm{mL}$ ) because of poor quality and were excluded from further analyses. At the $0.5 \mathrm{IU} / \mathrm{mL}$ cutoff, only six raccoon sera reported with RVNA less than $1 \mathrm{IU} / \mathrm{mL}$ were excluded.

A subset of 325 raccoon sera that tested within the range of $0.125-0.5 \mathrm{IU} / \mathrm{mL}$ at the NYSDOH laboratory were independently tested at Kansas State University to quantify RVNA titers in IU/ $\mathrm{mL}$ using a standard rapid fluorescent focus inhibition test (Yager and Moore 2015), and in duplicate at the US Department of Agriculture National Wildlife Research Center (Fort Collins, Colorado, USA) to quantify percent inhibition values using a commercial blocking enzymelinked immunosorbent assay (BioPro Rabies ELISA, OK Servis, Prague, Czech Republic) following the manufacturer's instructions (see Supplementary Material Table S1).

\section{Tetracycline biomarker and age determination}

Animal teeth were shipped to Matson's Laboratory LLC (Manhattan, Montana, USA) for TTCC detection and age determination. An ultraviolet light at $\times 100$ magnification with a Leitz compound microscope (Leica Microsystems $\mathrm{GmbH}$, Wetzlar, Germany) was used to detect TTCC. A total of 477 raccoons and 30 striped skunks were not evaluated for TTCC $(11.0 \%$ and $14.9 \%$ of records, respectively). The cementum annuli count method was used for determining ages (Johnston et al. 1987). Animal body size, weight, and reproductive status were also used in the field for classifying individuals as adults or juveniles. Whenever ages determined by cementum annuli were available, they were preferentially used as the most accurate estimate of animal age (see Supplementary Material Fig. S1). Relative age data (i.e., adult or juvenile) were available 
for 415 raccoons and 42 striped skunks. In either case, juvenile refers to an animal less than $1 \mathrm{yr}$ of age.

\section{Statistical methods}

We conducted two types of generalized linear mixed model (GLMM) analyses, one at the individual-animal level and one at the within-cell population level. Only raccoons were included in analyses, and recaptured individuals were included in both. We used package lme4 in RStudio (v 0.99.903; Bates et al. 2015). Study cell was treated as a random effect and nested within location (treatment history before 2012). Model goodness of fit was assessed using the marginalized and conditional $R^{2}$ (Nakagawa and Schielzeth 2013). We performed model selection using Akaike's information criterion corrected for small sample sizes (AICc; Burnham and Anderson 2002) and considered RVNA seroprevalence estimates using low $(0.125 \mathrm{IU} / \mathrm{mL})$ and high $(0.5 \mathrm{IU} / \mathrm{mL})$ cutoffs.

For the individual-level GLMM, we also treated year as a random effect. The RVNA status of individual raccoons was the binomial response variable, with sex (male or female), age (years), sampling period (pre- or post-ORV), and cell location (southern naïve or northern historic VRG) as fixed effects. To account for missing sex classifications for 31 raccoons, we converted sex to a numeric vector with males as 1 , females as 0 , and missing as 0.5 . We used age estimated from premolars when available. From a total of 415 raccoons missing an age determined from a premolar, we assigned 86 raccoons classified in the field as juveniles age $0 \mathrm{yr}$, and 329 raccoons classified in the field as adults age $2.62 \mathrm{yr}$ (i.e., the mean of a negative binomial distribution fit to the adult data). The candidate models with a change in Akaike's information criterion corrected for small sample sizes of less than two from the top model were recognized as competitive models. For the population-level GLMM, the proportional difference in the RVNA seroprevalence or TTCC prevalence of the raccoon population pre- and post-ORV within each cell and year were the continuous response variables, with fixed effects of location and year. Exact 95\% confidence interval (CI) were calculated on estimated proportions. Finally, we generated descriptive statistics for recaptured raccoons, with a focus on RVNA status within and across years.

\section{RESULTS}

Across the $3 \mathrm{yr}$ of the field trial, a total of 4,505 target animals were captured and sampled for RVNA (Table 2), of which
$94.8 \%(4,269 / 4,505)$ were raccoons, $4.4 \%$ $(198 / 4,505)$ were striped skunks, $0.4 \%$ (19/ $4,505)$ were fishers, $0.3 \%(12 / 4,505)$ were gray foxes, $0.09 \%(4 / 4,505)$ were red foxes, and $0.07 \%(3 / 4,505)$ were coyotes. Among raccoons, 3,449 records were unique and 820 records were from recaptured individuals. The number of serum test results was greater at the higher RVNA cutoff $(n=4,562$, Table S2), where an additional 53 raccoon and four skunk sera were evaluated. Forty-one target animals were found dead or were euthanized during the study and $61 \%$ (25/41) were tested for RV antigens. Among euthanized target animals, 83\% (20/24) were tested for RV antigens. Thirteen of the euthanized animals had abnormal behavior or a lesion leading to a suspicion of rabies, but only 1 of the 20 adult male raccoons tested positive with raccoon $\mathrm{RV}$ variant. This raccoon was captured during the 2012 pre-ORV period.

The RVNA seroprevalence among the raccoon population was $27.3 \%(295 / 1,079$, 95\% CI: 24.8-30.1) before the distribution of ONRAB in 2012. The raccoons in the northern cells demonstrated higher RVNA seroprevalence at $29.9 \%(218 / 728,95 \% \mathrm{CI}$ : 26.7-33.4) compared with $21.9 \%$ (77/351, 95\% CI: 17.9-26.6) in raccoons from southern cells (Table 2). Raccoons in the northern cells always had lower RVNA seroprevalences compared with raccoons from the southern cells post-ORV during each year, although the difference between locations was marginal at the higher RVNA cutoff (Table 2 and Table S2). The overall post-ORV RVNA seroprevalence was $68.5 \%$ (1,063/1,551, 95\% CI: 66.2 70.8 ) in the raccoon population during this study, or $53.4 \%$ (844/1,581, 95\% CI: 50.9 $55.8)$ considering the higher RVNA cutoff.

The top population-level GLMM of RVNA seroconversion to ORV included a year effect (Table 3). The marginalized $R^{2}$ and the conditional $R^{2}$ of the model were 0.626 and 0.740 , respectively. The impact of the annual ONRAB ORV decreased across the 3-yr study (Fig. 2). The RVNA seroprevalence in the raccoon population increased by an average of $42 \%$ after ONRAB ORV during year 1 and $20 \%$ during year 2 , but no further gains were 


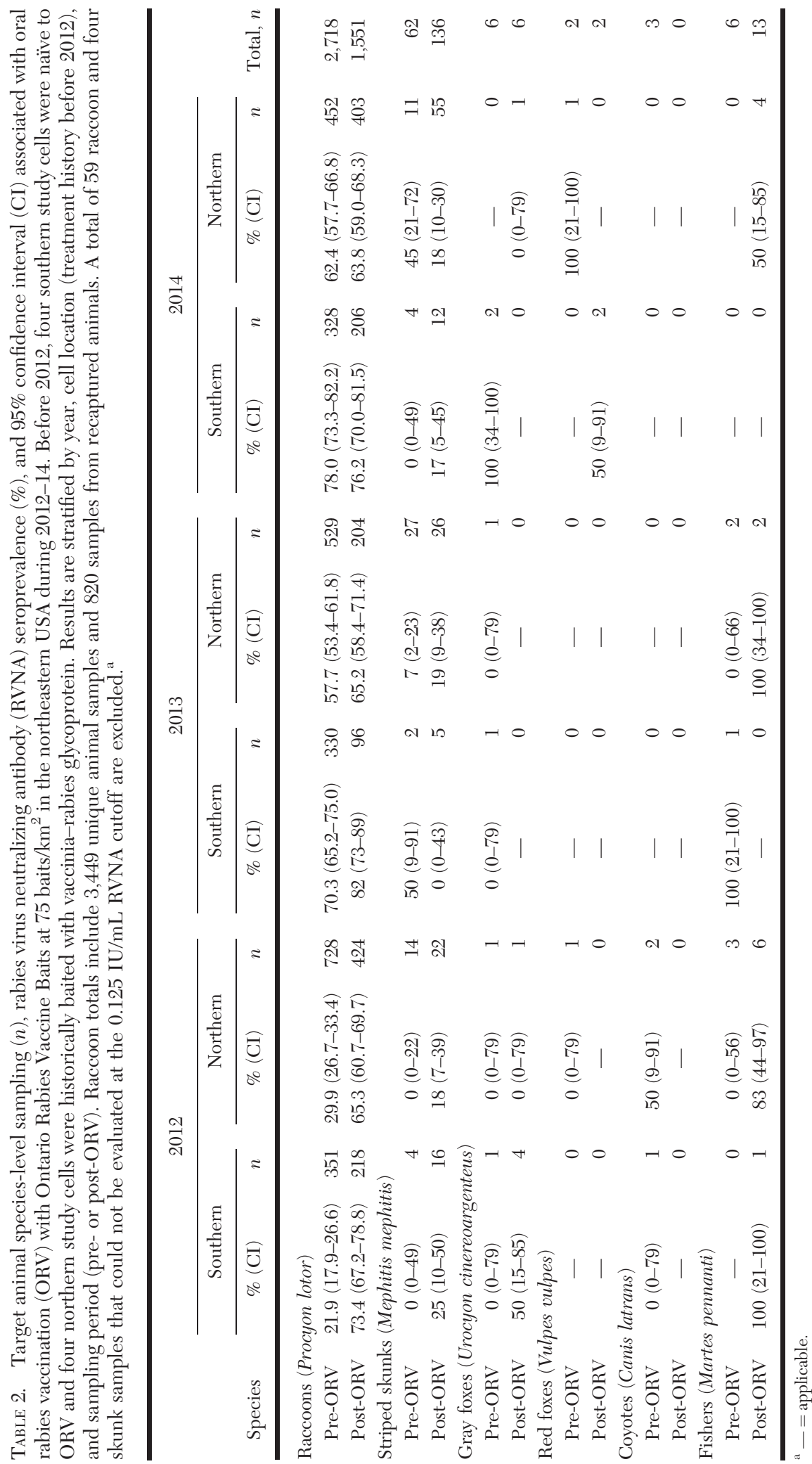


TABLE 3. Raccoon (Procyon lotor) population-level linear mixed-model selection for rabies virus neutralizing antibody (RVNA) response to oral rabies vaccination with Ontario Rabies Vaccine Baits at 75 baits $/ \mathrm{km}^{2}$ in the northeastern USA during 2012-14, on the basis of Akaike's information criterion corrected for small sample sizes (AICc) and a RVNA cutoff of $0.125 \mathrm{IU} / \mathrm{mL}$. Regarding location, four southern study cells were naïve to oral rabies vaccination and four northern study cells were historically baited with vaccinia-rabies glycoprotein before 2012 .

\begin{tabular}{llcccc}
\hline \multicolumn{1}{c}{ Model } & $K^{\mathrm{a}}$ & $\mathrm{AICc}^{\mathrm{b}}$ & $\Delta \mathrm{AICc}^{\mathrm{c}}$ & $\omega^{\mathrm{d}}$ & $-2 \log (\mathrm{L})^{\mathrm{e}}$ \\
\hline Year & 5 & -14.53 & 0 & 0.63 & 13.93 \\
Year×location+year+location & 7 & -12.43 & 2.10 & 0.22 & 16.72 \\
Year+location & 6 & -11.69 & 2.85 & 0.15 & 14.31 \\
Intercept & $4^{\mathrm{f}}$ & 7.20 & 21.74 & 0 & 1.45 \\
Location & 5 & 9.98 & 24.51 & 0 & 1.68 \\
\hline
\end{tabular}

${ }^{a} K=$ number of parameters in the model including random effects and variance.

${ }^{\mathrm{b}} \mathrm{AICc}=$ second-order Akaike's information criterion

${ }^{\mathrm{c}} \triangle \mathrm{AICc}=$ difference in AICc value from the top model.

d $\omega=$ Akaike weight or relative support for a given model.

e $-2 \log (\mathrm{L})=$ twice the negative log-likelihood value.

${ }^{\mathrm{f}}$ The intercept model has four parameters: 1) intercept parameter of $B_{0}, 2$ ) random effect of cell, 3) random effect of location, and 4) variance parameter for the normal distribution.

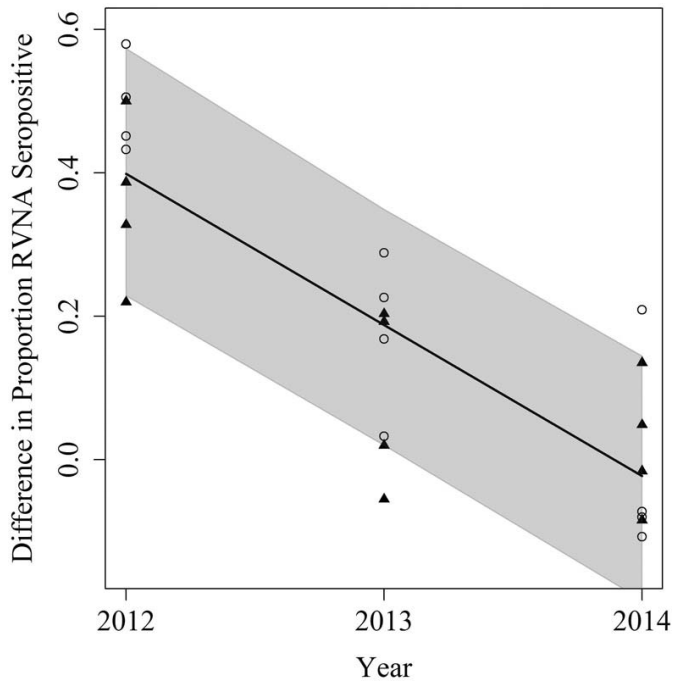

Figure 2. Difference in the rabies virus neutralizing antibody (RVNA) seropositive proportion of raccoons (Procyon lotor) between pre- and post-oral rabies vaccination (ORV) for each cell and year for the evaluation of Ontario Rabies Vaccine Bait distribution at 75 baits $/ \mathrm{km}^{2}$ in the northeastern USA during 2012-14, using a RVNA cutoff of 0.125 $\mathrm{IU} / \mathrm{mL}$. Southern study cells (hollow circles) were naïve to ORV before 2012, and northern cells (filled triangles) had been baited with vaccinia-rabies glycoprotein before 2012 . observed during year 3. Model selection results were similar considering a higher RVNA cutoff (Table S3). At the higher cutoff, RVNA seroprevalence in the raccoon population increased by an average of $34 \%$ during year $1,21 \%$ during year 2 , and $9 \%$ during year 3 (Fig. S2). The top population-level model of the change in TTCC prevalence among raccoons included a year effect (Table S4), with a marginalized and conditional $R^{2}$ of 0.584 . The TTCC prevalence in the raccoon population increased by an average of $46 \%$ during year 1, 29\% during year 2, and $12 \%$ during year 3 (Fig. S3).

For the individual-level analysis (Table S5), there were nine competitive models for the probability of an individual raccoon being RVNA seropositive (Table S6). The top model (m100) included two-way interactions of period $\times$ sex, period $\times$ age, and period $\times$ location, with a marginalized and conditional $R^{2}$ of 0.136 and 0.212 , respectively. Female and male raccoons were more likely to be seropositive during post-ORV sampling periods, with no difference between the sexes within periods (Fig. 3). Older raccoons were more likely to be seropositive, especially during the pre-ORV period (Fig. 4). Raccoons in the southern cells were more likely to be seropositive than raccoons in the northern 


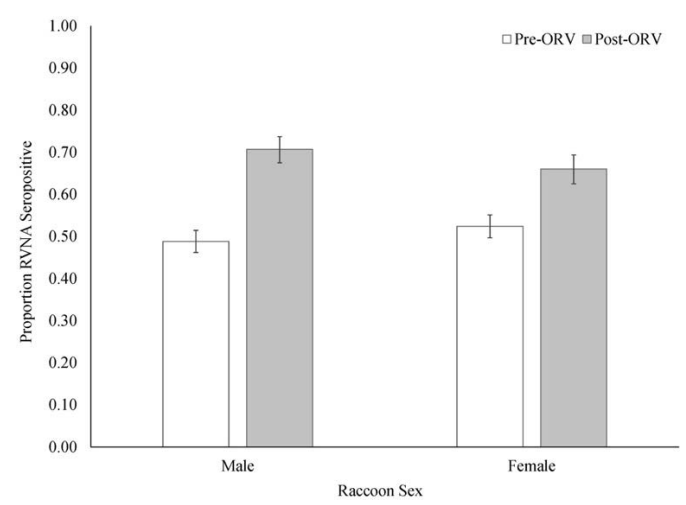

Figure 3. Proportion of male and female raccoons (Procyon lotor) seropositive for rabies virus neutralizing antibodies (RVNA) during pre- (white bars) and post-oral rabies vaccination (ORV; gray bars) sampling periods for the evaluation of Ontario Rabies Vaccine Bait distribution at 75 baits $/ \mathrm{km}^{2}$ in the northeastern USA during 2012-14, using a RVNA cutoff of 0.125 IU/mL. Error bars reflect $95 \%$ confidence intervals on estimated proportions.

cells, regardless of sampling period (Fig. 5). There were seven competitive models at the higher RVNA cutoff, and the top model (m095) included two-way interactions of period $\times$ sex, period $\times$ age, age $\times$ sex, and location $\times$ sex (Table S7), with a marginalized and conditional $R^{2}$ of 0.136 and 0.194 , respective-

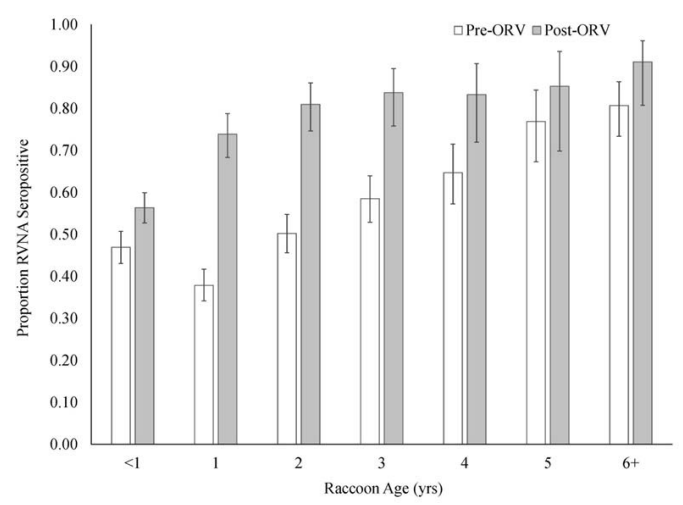

FiguRe 4. Proportion of raccoons (Procyon lotor) seropositive for rabies virus neutralizing antibodies (RVNA) across yearly age classes during pre- (white bars) and post-oral rabies vaccination (ORV; gray bars) sampling periods for the evaluation of Ontario Rabies Vaccine Bait distribution at 75 baits $/ \mathrm{km}^{2}$ in the northeastern USA during 2012-14, using a RVNA cutoff of $0.125 \mathrm{IU} / \mathrm{mL}$. Error bars reflect $95 \%$ confidence intervals on estimated proportions.

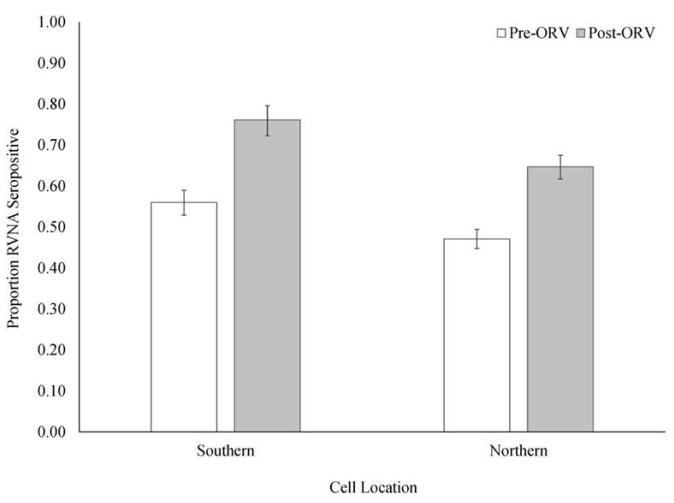

Figuke 5. Proportion of raccoons (Procyon lotor) seropositive for rabies virus neutralizing antibodies (RVNA) in southern and northern locations during pre- (white bars) and post-oral rabies vaccination (ORV; gray bars) sampling periods for the evaluation of Ontario Rabies Vaccine Bait distribution at 75 baits/ $\mathrm{km}^{2}$ in the northeastern USA during 2012-14, using a RVNA cutoff of $0.125 \mathrm{IU} / \mathrm{mL}$. Southern locations were naïve to ORV before 2012, and northern locations had been baited with vaccinia-rabies glycoprotein before 2012. Error bars reflect 95\% confidence intervals on estimated proportions.

ly. The period $\times$ sex and period $\times$ age trends were the same as reported for the lower cutoff. Male and female raccoons were more likely to be seropositive in the southern compared with northern locations, and the probability of being seropositive increased with age in both male and female raccoons.

Among recaptured raccoons, 50.3\% (343/ 682, 95\% CI: 46.6-54.0) were RVNA negative upon initial capture, with $58.3 \%$ (200/343, 95\% CI: 53.0-63.4) of the seronegative raccoons seroconverting between successive capture events. Higher levels of seroconversion were documented among raccoons recaptured during post- compared with preORV periods (Table 4). For raccoons that were RVNA seropositive upon initial capture, 82.6\% (280/339, 95\% CI: 78.2-86.3) were seropositive upon recapture.

\section{DISCUSSION}

The distribution of ONRAB during 2012 at 75 baits $/ \mathrm{km}^{2}$ and 750 -m flight-line spacing in the northeastern US field trial achieved a 
TABLE 4. Rabies virus neutralizing antibody seroprevalence (\%) and corresponding sample size $(n)$ for 343 captured and recaptured raccoons (Procyon lotor) that were seronegative upon initial capture on the basis of a cutoff of $0.125 \mathrm{IU} / \mathrm{mL}$, by sampling period relative to oral rabies vaccination (ORV) with Ontario Rabies Vaccine Baits at 75 baits $/ \mathrm{km}^{2}$ in the northeastern USA during 2012-14. ${ }^{\mathrm{a}}$

\begin{tabular}{|c|c|c|c|c|c|c|c|c|c|c|}
\hline \multirow[b]{4}{*}{ Year captured } & \multicolumn{10}{|c|}{ Year recaptured } \\
\hline & \multirow{2}{*}{\multicolumn{2}{|c|}{$\frac{2012}{\text { Post-ORV }}$}} & \multicolumn{4}{|c|}{2013} & \multicolumn{4}{|c|}{2014} \\
\hline & & & \multicolumn{2}{|c|}{ Pre-ORV } & \multicolumn{2}{|c|}{ Post-ORV } & \multicolumn{2}{|c|}{ Pre-ORV } & \multicolumn{2}{|c|}{ Post-ORV } \\
\hline & $\%$ & $n$ & $\%$ & $n$ & $\%$ & $n$ & $\%$ & $n$ & $\%$ & $n$ \\
\hline 2012 & 62 & 131 & 53 & 75 & 86 & 7 & 63 & 19 & 91 & 11 \\
\hline 2013 & - & - & 一 & - & 60 & 30 & 29 & 24 & 88 & 8 \\
\hline 2014 & - & - & 一 & - & - & - & - & - & 50 & 38 \\
\hline
\end{tabular}

${ }^{\mathrm{a}}-=$ not applicable

post-ORV RVNA seroprevalence of $73.4 \%$ (160/218, 95\% CI: 67.2-78.8) among the ORV-naïve raccoon population, which is the highest observed by Wildlife Services in an ORV-naïve area with similar treatment (Slate et al. 2014). The distribution of ONRAB during 2012 also achieved a post-ORV RVNA seroprevalence of $65.3 \%$ (277/424, 95\% CI: 60.7-69.7) among the raccoon population with a history of prior ORV. Estimated RVNA seroprevalence was uniformly lower using a higher cutoff of $0.5 \mathrm{IU} / \mathrm{mL}$, but these values were comparable with the levels observed in raccoon populations following the distribution of ONRAB at 75 baits $/ \mathrm{km}^{2}$ in an area previously treated with ORV in southwestern Ontario (Rosatte et al. 2009) and in an area with a limited history of trap-vaccinaterelease in New Brunswick (Fehlner-Gardiner et al. 2012).

Baseline RVNA seroprevalence was $21.9 \%$ and $29.9 \%$ among raccoons sampled from southern and northern cells, respectively, before ONRAB bait distribution in 2012. At a higher RVNA cutoff, these estimates were 8.8\% (31/351, 95\% CI: $6.3-12.3$ ) and $16.2 \%$ (119/733, 95\% CI: 13.7-19.1) in southern and northern cells, respectively. Regardless of the RVNA cutoff used, it is well recognized that background levels of RVNA in raccoon populations can result from apparently sublethal exposures to RV (i.e., abortive infections; McLean 1971; Bigler et al. 1973; Slate et al. 2014). One of the four southern cells had
RVNA seroprevalence of $36.9 \%$ (55/149, $95 \%$ CI: 29.6-44.9) before ORV in 2012 and evidence of an elevated number of rabies cases during the year before ORV, whereas raccoons in the other three southern cells had 9\% (4/46, 95\% CI: $3-20)$ to $12.0 \%(12 / 100$, 95\% CI: 7.0-19.8) RVNA seroprevalence. Of raccoons sampled from the southern cells before ONRAB distribution in 2012, 27\% (81/ $304)$ were juveniles and $22 \%$ (18/81, $95 \%$ CI: 15-32) were RVNA seropositive, compared with $24.2 \%$ (54/223, 95\% CI: $19.1-30.3)$ of adults. Thus, even if passive maternal RVNAs were present in the juvenile cohort, it does not appear that it biased the seroprevalence estimate for the southern cells before ONRAB distribution. In contrast, the four northern cells had similar RVNA seroprevalence before ONRAB distribution (range of $26.1 \%$ [47/180, 95\% CI: $20.2-33.0]$ up to $33.0 \%$ [61/185, 95\% CI: 26.6-40.0]) and comparable levels with the national average of $30 \%$ from V-RGbaited areas in the US that consider a RVNA cutoff of $0.06 \mathrm{IU} / \mathrm{mL}$ (Slate et al. 2009).

Even though TTCC deposition may be lower in premolar teeth than in canine teeth or mandibular bone (Algeo et al. 2013; Slate et al. 2014), the population TTCC response was consistent with the RVNA analysis in estimating the fractions of the raccoon population affected by ORV in this study. The top population-level models of RVNA seroconversion and TTCC response during the field trial did not include location, and thus were similar 
across all study cells (Fig. 2 and Figs. S2, S3). Pooling all years of data, the fraction of RVNA seropositive raccoons was greater in the southern cells compared with the northern cells during both sampling periods. This may be an artifact of differences in raccoon densities between the locations rather than a legacy effect of treatment history before 2012 . Across all $3 \mathrm{yr}$, identical trapping effort in the northern cells tended to result in the capture of twice as many raccoons per sampling period compared with the southern cells (mean of 114 compared with 64). Since the baiting density was the same for all cells, there may have been more baits available to raccoons in the southern cells given a potentially lower density of raccoons, and assuming nontarget competition for baits and other potential environmental factors were similar across cells and years. This explanation is consistent with another study, which reported that increasing raccoon abundance was negatively associated with the probability of an individual raccoon being seropositive for RV antibody (Mainguy et al. 2012).

We present evidence of a saturating effect in RVNA seroconversion in the raccoon population after successive annual ORV campaigns. Similar trends have been reported previously (Sattler et al. 2009; Mainguy et al. 2012). Results observed in this study may be specific to the relatively large size of the area baited (about 7,189 $\mathrm{km}^{2}$ ). Smaller ORV areas may be subject to greater edge effects, and thus greater external disease pressure and immigration of individuals from unbaited areas, leading to longer delays in seroprevalence saturation and reduction of case burden. During this study, older raccoons were more likely to be seropositive than younger raccoons. An increasing RV antibody seroprevalence with raccoon age was also reported in a prior study investigating the use of ONRAB in southern Quebec (Mainguy et al. 2012). Nevertheless, over $85 \%$ of raccoons sampled in the current study were equal to or less than $3 \mathrm{yr}$ old. Thus, significant turnover in the susceptible fraction of the raccoon population is possible $3 \mathrm{yr}$ after an ORV campaign, potentially framing a minimum annual ORV program of 2 to $3 \mathrm{yr}$ to achieve herd immunity saturation for elimination on larger land masses.

A simulation study concluded that raccoon population immunity of $60 \%$ leads to a dramatic reduction in rabies cases, even under varying assumptions about habitat quality and population connectivity (Rees et al. 2013). A more recent simulation study using empirically derived contact data found that when RV was introduced at the start of the breeding season in a "suburban" (i.e., high-density) raccoon population, vaccination coverage in excess of $80 \%$ would be necessary to prevent an outbreak (Reynolds et al. 2015). There is likely variation in coverage necessary between rural and suburban settings, where raccoon densities vary from low to high, respectively, with potential impacts for contact behavior and disease spread (Hadidian et al. 2010). A summary of 58 studies conducted by the NRMP in the northeastern US study area during 1997-2010 determined a mean raccoon abundance index of 8.0 (range of 2.1-17) raccoons $/ \mathrm{km}^{2}$ in agricultural mixed-forest habitats. Simulation modeling tools, which can further examine the impacts of variable host densities, in addition to habitat-based contact and movement across complex landscapes, will be informative for managers planning ORV interventions (Elmore et al. 2017; Tardy et al. 2018).

The RVNA seroprevalence levels documented in this study are likely adequate for stopping RV transmission and support and expand upon the results from the West Virginia ONRAB field trial (Slate et al. 2014), as well as earlier cross-border evaluations (Fehlner-Gardiner et al. 2012; Mainguy et al. 2013). Raccoon RV variant cases have decreased in the study area ORV zone since the distribution of ONRAB began in 2012 (Fig. 1). Before ONRAB distribution (during 2011 and the summer of 2012), there were 27 confirmed cases of raccoon rabies throughout the zone and in 2016 there were only two cases. However, maintaining robust enhanced rabies surveillance in this region will yield further evidence to the effectiveness of this baiting strategy. Although none of the study 
cells was located in the area where ONRAB was applied at $150 \mathrm{baits} / \mathrm{km}^{2}$, we speculate that the levels of RVNA in the raccoon population in the higher bait density area were at least as high as those observed in the area baited at 75 baits $/ \mathrm{km}^{2}$ during this study. Taken together, the levels of RVNA achieved in the raccoon population baited with $\mathrm{ON}$ RAB during this study should establish sufficient raccoon population immunity to disrupt the circulation of raccoon $\mathrm{RV}$ in agricultural mixed-forest habitats of this region.

\section{ACKNOWLEDGMENTS}

We thank US Department of Agriculture Wildlife Services personnel in New York, Vermont, and New Hampshire who conducted the fieldwork and specifically Dan Morgan, Ben Baker, and Fred Pogmore for their extra efforts and significant contributions to these field trials. We also thank Amy Davis for assistance with the statistical analysis.

\section{SUPPLEMENTARY MATERIAL}

Supplementary material for this article is online at http://dx.doi.org/10.7589/2017-09-242.

\section{LITERATURE CITED}

Algeo TP, Norhenberg G, Hale R, Montoney A, Chipman RB, Slate D. 2013. Oral rabies vaccination variation in tetracycline biomarking among Ohio raccoons. I Wildl Dis 49:332-337.

AVMA (American Veterinary Medical Association). 2013. AVMA guidelines for the euthanasia of animals: 2013 edition. https://www.avma.org/KB/Policies/ Documents/euthanasia.pdf. Accessed September 2017.

Bates D, Maechler M, Bolker B, Walker S. 2015. Fitting linear mixed-effects models using lme4. J Stat Softw 67:1-48.

Beyer HL. 2004. Hawth's analysis tools for ArcGIS. http://www.spatialecology.com/htools. Accessed January 2012.

Beyer HL. 2012. Geospatial modeling environment (Version 0.7.3.0). http://www.spatialecology.com/ gme. Accessed January 2013 and January 2014.

Bigler WJ, Mclean RG, Trevino HA. 1973. Epizootiologic aspects of raccoon rabies in Florida. Am J Epidemiol 98:326-335.

Blanton JD, Niezgoda M, Hanlon CA, Swope CB, Suckow J, Saidy B, Nelson K, Chipman RB, Slate D. 2018. Evaluation of oral rabies vaccination: Protection against rabies in wild-caught raccoons. $J$ Wildl Dis 54:520-527.

Burnham KP, Anderson DR. 2002. Model selection and multimodel inference: A practical information-theroretic approach. 2nd Ed. Springer-Verlag, New York, New York, 488 pp.

Centers for Disease Control and Prevention. 2017. Protocol for postmortem diagnosis of rabies in animals by direct fluorescent antibody testing. https://www.cdc.gov/rabies/pdf/RabiesDFASPv2.pdf. Accessed September 2017.

Elmore SA, Chipman RB, Slate D, Huyvaert KP, Vercauteren KC, Gilbert AT. 2017. Management and modeling approaches for controlling raccoon rabies: The road to elimination. PLoS Negl Trop Dis 11:e0005249.

Fehlner-Gardiner C, Rudd R, Donovan D, Slate D, Kempf L, Badcock J. 2012. Comparing ONRAB ${ }^{(\mathrm{R})}$ and RABORAL V-RG ${ }^{(\mathrm{R})}$ oral rabies vaccine field performance in raccoons and striped skunks, New Brunswick, Canada, and Maine, USA. J Wildl Dis 48: 157-167.

Graham FL, Prevec L. 1992. Adenovirus-based expression vectors and recombinant vaccines. In: Vaccines: new approaches to immunological problems, Ellis RW, editor. Butterworth-Heinemann, Boston, Massachusetts, pp. 363-390.

Hadidian J, Prange S, Rosatte R, Riley SP, Gehrt SD 2010. Raccoons (Procyon lotor). In: Urban carnivores: Ecology, conflict, and conservation, Gehrt SD, Riley SP, Cypher BL, editors. The Johns Hopkins University Press, Baltimore, Maryland, pp. 35-47.

Hanlon CA, Niezgoda M, Hamir AN, Schumacher C, Koprowski H, Rupprecht CE. 1998. First North American field release of a vaccinia-rabies glycoprotein recombinant virus. J Wildl Dis 34:228-239.

Hanlon CA, Rupprecht CE. 1998. The reemergence of rabies. In: Emerging infections 1, Scheld WM, Armstrong D, Hughes JM, editors. American Society for Microbiology Press, Washington, DC, pp. 59-80.

Homer C, Dewitz J, Yang L, Jin S, Danielson P, Xian G, Coulston J, Herold N, Wickham J, Megown K. 2015. Completion of the 2011 National Land Cover Database for the conterminous United StatesRepresenting a decade of land cover change information. Photogramm Eng Remote Sensing 81:345354.

Johnston DH, Joachim DG, Bachmann P, Kardong KV, Stewart REA, Dix LM, Strickland MA, Watt ID. 1987. Aging furbearers using tooth structure and biomarkers. In: Wild furbearer managment and conservation in North America, Novak M, Baker JA, Obbard ME, Malloch B, editors. Ontario Trappers Association, North Bay, Ontario, Canada, pp. 228243.

Mainguy J, Fehlner-Gardiner C, Slate D, Rudd RJ. 2013. Oral rabies vaccination in raccoons: Comparison of $\mathrm{ONRAB}^{\circledR}$ and RABORAL V-RG ${ }^{\circledR}$ vaccine-bait field performance in Québec, Canada and Vermont, USA. J Wildl Dis 49:190-193. 
Mainguy J, Rees EE, Canac-Marquis P, Bélanger D, Fehlner-Gardiner C, Séguin G, Larrat S, Lair S, Landry F, Côté N. 2012. Oral rabies vaccination of raccoons and striped skunks with $\mathrm{ONRAB}^{\circledR}$ baits: Multiple factors influence field immunogenicity. $J$ Wildl Dis 48:979-990.

Maki J, Guiot A-L, Aubert M, Brochier B, Cliquet F, Hanlon C, King R, Oertli EH, Rupprecht CE, Schumacher C, et al. 2017. Oral vaccination of wildlife using a vaccinia-rabies glycoprotein recombinant virus vaccine (RABORAL V-RG ${ }^{\circledR}$ ): A global review. Vet Res 48:57-83.

McLean RG. 1971. Rabies in raccoons in the Southeastern United States. J Infect Dis 123:680-681.

Moore SM, Gilbert A, Vos A, Freuling CM, Ellis C, Kliemt J, Müller T. 2017. Rabies virus antibodies from oral vaccination as a correlate of protection against lethal infection in wildlife. Trop Med Infect Dis 2:31-55.

Nakagawa S, Schielzeth H. 2013. A general and simple method for obtaining $R^{2}$ from generalized linear mixed-effects models. Methods Ecol Evol 4:133-142.

Nettles VF, Shaddock JH, Sikes RK, Reyes CR. 1979. Rabies in translocated raccoons. Am J Public Health 69:601-602.

Olson CA, Mitchell KD, Werner PA. 2000. Bait ingestion by free-ranging raccoons and nontarget species in an oral rabies vaccine field trial in Florida. $J$ Wildl Dis 36:734-743.

Rees EE, Pond BA, Tinline RR, Béelanger D. 2013. Modelling the effect of landscape heterogeneity on the efficacy of vaccination for wildlife infectious disease control. J Appl Ecol 50:881-891.

Reynolds JJH, Hirsch BT, Gehrt SD, Craft ME. 2015. Raccoon contact networks predict seasonal susceptibility to rabies outbreaks and limitations of vaccination. J Anim Ecol 84:1720-1731.

Robbins AH, Borden MD, Windmiller BS, Niezgoda M, Marcus LC, O'Brien SM, Kreindel SM, McGuill MW, DeMaria A Jr, Rupprecht CE, et al. 1998. Prevention of the spread of rabies to wildlife by oral vaccination of raccoons in Massachusetts. J Am Vet Med Assoc 213:1407-1412.

Rosatte RC, Donovan D, Davies JC, Allan M, Bachmann P, Stevenson B, Sobey K, Brown L, Silver A, Bennett $\mathrm{K}$, et al. 2009. Aerial distribution of $\mathrm{ONRAB}^{(\mathrm{R})}$ baits as a tactic to control rabies in raccoons and striped skunks in Ontario, Canada. J Wildl Dis 45:363-374.

Rosatte RC, Donovan D, Davies JC, Brown L, Allan M, Von Zuben V, Bachmann P, Sobey K, Silver A, Bennett K, et al. 2011. High-density baiting with $\mathrm{ONRAB}^{\circledR}$ rabies vaccine baits to control Arcticvariant rabies in striped skunks in Ontario, Canada. J Wildl Dis 47:459-465.
Roscoe DE, Holste WC, Sorhage FE, Campbell C, Niezgoda M, Buchannan R, Diehl D, Niu HS, Rupprecht CE. 1998. Efficacy of an oral vacciniarabies glycoprotein recombinant vaccine in controlling epidemic raccoon rabies in New Jersey. $J$ Wildl Dis 34:752-763.

Rupprecht CE, Smith JS. 1994. Raccoon rabies: The reemergence of an epizootic in a densely populated area. Semin Virol 5:155-164.

Sattler AC, Krogwold RA, Wittum TE, Rupprecht CE, Algeo TP, Slate D, Smith KA, Hale RL, Nohrenberg GA, Lovell CD, et al. 2009. Influence of oral rabies vaccine bait density on rabies seroprevalence in wild raccoons. Vaccine 27:7187-7193.

Slate D, Algeo TP, Nelson KM, Chipman RB, Donovan D, Blanton JD, Niezgoda M, Rupprecht CE. 2009. Oral rabies vaccination in North America: Opportunities, complexities, and challenges. PLoS Negl Trop Dis 3:e549.

Slate D, Chipman RB, Algeo TP, Mills SA, Nelson KM, Croson CK, Dubovi EJ, Vercauteren K, Renshaw RW, Atwood T, et al. 2014. Safety and immunogenicity of Ontario Rabies Vaccine Bait (ONRAB) in the first US field trial in raccoons (Procyon lotor). J Wildl Dis 50:582-595.

Slate D, Rupprecht CE, Rooney JA, Donovan D, Lein DH, Chipman RB. 2005. Status of oral rabies vaccination in wild carnivores in the United States. Virus Res 111:68-76.

Szanto AG, Nadin-Davis SA, Rosatte RC, White BN. 2011. Re-assessment of direct fluorescent antibody negative brain tissues with a real-time PCR assay to detect the presence of raccoon rabies virus RNA. J Virol Methods 174:110-116.

Tardy O, Massé A, Pelletier F, Fortin D. 2018. Interplay between contact risk, conspecific density, and landscape connectivity: An individual-based modeling framework. Ecol Modell 373:25-38.

Trimarchi CV, Rudd RD, Safford M Jr. 1996. An in vitro virus neutralization test for rabies antibody. In: Laboratory techniques in rabies, 4th Ed., Meslin FX, Kaplan MM, Koprowski H, editors. World Health Organization, Geneva, Switzerland, pp. 193199.

Yager ML, Moore SM. 2015. The rapid fluorescent focus inhibition test. In: Current laboratory techniques in rabies diagnosis, research and prevention, Vol. 2., Rupprecht CE, Nagarajan T, editors. Academic Press, San Diego, California, pp. 199-215.

Submitted for publication 29 September 2017. Accepted 7 March 2018. 